Beata Rogowska

Jan Kochanowski University in Kielce

Institute of Law, Economics and Administration

e-mail: beat78@ujk.edu.pl

\title{
Relacje między etyką, prawem i ekonomią: analiza poglądów Adama Smitha
}

\section{The relationships between ethics, law and economics: Adam Smith's views analysis}

Adam Smith is commonly viewed as the founding father of economics. This conviction stems from the publication of The Wealth of Nations in 1776. Smith's works are chiefly examined in terms of economics. The discovery of reports of his Lectures on Jurisprudence and defining them as a "bridge" between his ethics, law and economics allows researchers to analyze Smith's work from a fresh perspective. The aim of the paper is to discuss complex relationships between ethics included in The Theory of Moral Sentiments and general principles of law and economics. The main conclusion of this paper is that Smith emphasized the mutual complementation of moral and legal norms in the context of the economic development of the commercial society.

Keywords: government, jurisprudence, natural law, ethics, impartial spectator

JEL Classification: B12, B31, K1

\section{Wprowadzenie}

Celem pracy jest analiza Wykładów o jurysprudencji Adama Smitha jako łącznika między teoriami etycznymi a ekonomicznymi. Autorka stawia tezę o wzajemnej współzależności koncepcji etycznych, ekonomicznych i prawnych w twórczości Smitha. Wzajemne przenikanie się jego dzieł, z uwzględnieniem chronologii ich 
powstania, świadczy o dojrzewaniu autora do budowania teorii ekonomicznych, których nie da się analizować w ramach jednej dyscypliny naukowej - należy wziąć pod uwagę jego osiągnięcia z zakresu etyki oraz jurysprudencji.

W latach 1751-1764 Smith zajmował katedrę filozofii moralnej na uniwersytecie w Glasgow ${ }^{1}$. Na podstawie wygłoszonych tam przez niego wykładów w 1869 r. wydano drukiem Lectures on Justice, Police, Revenue and Arms ${ }^{2}$. Należy podkreślić, że ówczesna filozofia moralna nie ograniczała się do etyki, lecz obejmowała szereg dyscyplin, stanowiących dziś odrębne nauki szczegółowe. W ujęciu Smitha składała się ona z czterech części: ekonomii, etyki, teorii sprawiedliwości i filozofii prawa (Haakonssen, 1989, s. 49; Sandmo, 2011, s. 32).

Smith nie wyodrębniał etyki i moralności, w związku z tym stosował oba terminy zamiennie ${ }^{3}$. Należy podkreślić, że obserwacje Smitha dotyczyły przede wszystkim: Szkocji, Wielkiej Brytanii oraz kontynentu europejskiego. Dlatego też w ujęciu etycznym podstawę stanowi tzw. szkockie oświecenie ${ }^{4}$, w ujęciu ekonomicznym istotną rolę odgrywa etap rozwoju gospodarczego ówczesnej Anglii i Szkocji (gospodarka przed rewolucją przemysłową), w ujęciu prawnym ważny

\footnotetext{
${ }^{1}$ Oficjalnego wyboru dokonano 9 stycznia $1751 \mathrm{r}$. Wykłady rozpoczął dopiero w październiku (po śmierci T. Craigiego, który objął katedrę po F. Hutchesonie). Pierwszy wykład z orzecznictwa jest datowany na 24 grudnia 1762 r. Wykłady z filozofii moralnej odbywały się w dwóch klasach: publicznej (80-90 studentów) i prywatnej (ok. 20 studentów). Uniwersytet w Glasgow był ówcześnie wiodącą uczelnią w Anglii (Brühlmeier, 2004, s. 10).

${ }^{2}$ Istnieją dwie wersje notatek z ówczesnych wykładów Smitha. Jedna z nich to wykłady z okresu 1762-1763, odnalezione przez J.M. Lothiana w 1958 r. Druga to notatki z lat 1763-1764, odkryte przez E. Cannana w 1896 r. W pracy analizie poddano: Lectures on Justice, Police, Revenue and Arms (1763 [1869], Oxford: Clarendon Press), Teorię uczuć moralnych (1989, Warszawa: PWN), Badania nad natura i przyczynami bogactwa narodów, t. I, II (1954, Warszawa: PWN). Autorka abstrahuje od szczegółowej analizy kolejnych wydań trzech kluczowych dzieł A. Smitha. Warto podkreślić, że WN za życia autora było wydawane 5 razy. TSM za życia Smitha miało sześć opracowanych przez niego wydań $(1759,1761,1767,1774,1781$ oraz 1790). Najwięcej merytorycznych poprawek dokonał w TMS (zwłaszcza wydania 1, 2, 6). LJ zawierają już poglądy obecne w WN, były jednak głoszone w czasie, gdy Szkot pracował nad trzecim wydaniem TMS. Warto podkreślić, że Smith zamierzał wykorzystać wykłady jako podstawę książki o jurysprudencji, ale nie ukończył pracy. Krótko przed śmiercią w 1790 r. wydał polecenie zniszczenia 16 tomów wszystkich jego rękopisów z wyjątkiem kilku powierzonych esejów (Smith, 1998, III). W pracy stosuje się anglojęzyczne skróty dzieł Smitha: Badania nad natura i przyczynami bogactwa narodów - WN, Wyktady o jurysprudencji - LJ, Teoria uczuć moralnych - TMS. Do opisu bibliograficznego dzieł A. Smitha wprowadzono oznaczenia wynikające ze struktury omawianych prac. Zestawienie zagadnień analizowanych zarówno w WN, jak i LJ zaprezentowano we Wstępie do LJ (Smith, 1869, s. 3; Chodorowski, 2002, s. 20, 51).

${ }^{3} \mathrm{Z}$ semantycznego punktu widzenia moralność i prawo mają wspólne korzenie. Istotne wydaje się jednak zdefiniowanie norm moralnych i prawnych. Abstrahując od złożonych różnic między tymi normami - prawne obowiązują z nakazu zewnętrznego, pochodzą od kompetentnego organu władzy publicznej i to przesądza o ich obowiązywaniu. Normy moralne mają uzasadnienie aksjologiczne - zaczynają obowiązywać, gdy w danej grupie społecznej upowszechni się przekonanie, że dane zachowanie jest czymś dobrym lub złym. Norma moralna obowiązuje w sytuacji, gdy uzyska akceptację danego adresata, który władny jest uznać, że jest ona dla niego wiążąca (internalizacja), pochodzi z wewnątrz (Klimczak, 1993, s. 23).

${ }^{4}$ Termin Scottish enlightenment użyty został po raz pierwszy w roku 1900 przez W.R. Scotta. Szkockie oświecenie zaczęło się w 1715 r., skończyło w 1832 r. Filozofowie szkoccy byli ściśle związani z trzema instytucjami: uniwersytetami, Kościołem i prawem. Smith należał do kręgu wybitnych myślicieli szkockich. Tworzył pod wpływem Hutchesona, Harringtona, Monteskiusza, Hume'a (Zabieglik, 1997, s. 44-47).
} 
jest system common law ${ }^{5}$. Dla wszystkich wymiarów znacząca wydaje się unia Anglii ze Szkocją z 1707 roku . W pracy wykorzystano metodę studiów literaturowych.

\section{Prawo - pomiędzy etyką a ekonomią}

Wykłady Smitha wpisują się w szerszą debatę o tym, czym jest prawo, jak powstaje i w jaki sposób wiąże się z zasadami moralnymi i rozwojem gospodarczym. Dla Smitha ekonomia była częścią nauki moralnej związaną z jurysprudencją (Piqué, 2016, s. 90), którą definiował jako „naukę, która bada ogólne zasady, które powinny być podstawą praw wszystkich narodów” (Smith, 1869, I, XII) oraz teorię reguł, według jakich rządy cywilne powinny być kierowane (VII, III) ${ }^{7}$.

Smith na wstępie podkreślał zasługi Grotiusa ${ }^{8}$ jako ojca ,systemu naturalne-

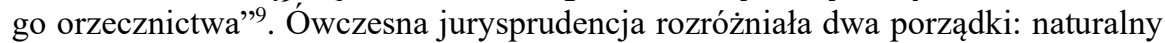
jako ideał (wzór normatywny) oraz stanowiony w konkretnych (cywilizowanych) warunkach społeczeństwa cywilnego ${ }^{10}$. Cztery główne obszary badań prawa to według Smitha: sprawiedliwość, policja, dochody i obrona narodowa. Początki ekonomii były mocno osadzone w paragrafie dotyczącym policji (Smith, 1896, I, $\S$ II), w którym autor łączył termin ,policja” z takimi pojęciami, jak bezpieczeństwo, czystość (w znaczeniu porządku publicznego). Należy wskazać, że termin ,policja” ma u Smitha zupełnie inne znaczenie niż współcześnie. Nazwa jest francuska, a pochodzi od greckiego politeia, które oznaczało politykę rządu cywilnego. W Anglii termin ten miał znaczenie węższe niż w niemieckim kameralizmie (MacCormick, 1981, s. 244).

\footnotetext{
${ }^{5}$ Najbardziej charakterystyczną cechą prawa angielskiego był jego dualizm. Najpierw bowiem wykształciło się prawo powszechne common law, a od XV w. rozwijał się równolegle do niego nowy system, zwany equity. Źródłem powstania common law było orzecznictwo sądów westminsterskich, equity powstało z kolei jako przejaw działalności Sądu Kanclerskiego. Smith precyzyjnie opisał złożoność angielskiego wymiaru sprawiedliwości, omawiając Sąd Spraw Pospolitych (Court of Common Pleas), Sąd Ławy Królewskiej (Court of King's Bench), Sąd Szachownicy (Court of Exchequer), akcentując różnice w relacji do Szkocji (Smith, 1869, I § VI, VIII, XII; Dziadzio, 2002, s. 180).

${ }^{6}$ Był to zarazem szczególny okres w dziejach Szkocji, która stała się częścią większego, szybko rozwijającego się organizmu politycznego - imperium brytyjskiego. W wyniku unii objęto Szkotów jurysdykcją sądów brytyjskich (prawo brytyjskie było bardziej surowe).

${ }^{7}$ Obecnie definiuje się ją jako: „ogólną wiedzę o prawie, która jest rodzajem filozofii prawa, ale zorientowanej na rozwiązywanie problemów dostrzeganych z perspektywy prawa i jego poszczególnych gałęzi” (Zirk-Sadowski, 2011, s. 19). Smith postrzegł ekonomię jako stosowaną filozofię moralną (Hühn, 2019, s. 1).

${ }^{8}$ Uznawał je za prawa uniwersalne, obowiązujące wszystkich ludzi w każdym czasie i niezależnie od szerokości geograficznej.

9 Orzecznictwo: łacińskie słowo jurisprudential; juris: prawo i ostrożność, rozwaga, mądrość, dalekowzroczność (Piqué, 2016, s. 90; Smith, 1869, I, § 1, XII).

${ }^{10} \mathrm{~W}$ XVIII wieku angielskie prawo nie było przedmiotem wykładów na uniwersytetach. Prawnicy byli kształceni przez praktykę. Dopiero sławny twórca komentarzy do prawa angielskiego W. Blackstone rozpoczął wykłady z common law w Oxfordzie.
} 
Smith interesował się przede wszystkim jednym $\mathrm{z}$ aspektów funkcjonowania policji, tzw. tanim towarem w relacji do bogactwa państwa (Dubber, 2005, s. 200). Społeczeństwo komercyjne według Smitha jest symbolem „taniości” wszystkich rodzajów towarów w państwie, co jest konsekwencją tzw. obfitości. Aby wyjaśnić przyczyny bogactwa, należało przeprowadzić badanie „obfitości”, które zdaniem Smitha sprowadzało się do analizy natury handlu i cen. Wzrastające potrzeby są konsekwencją postępu, którego podstawą było dążenie do utrzymania się jednostki. Zatem ,policja” to zbiór przepisów o handlu, rolnictwie i produkcji, regulowanych przez państwo, aby zachęcić do kreowania bogactwa kraju. W części dotyczącej przychodów, które opisują sposoby pozyskiwania funduszy niezbędnych do utrzymania i wdrożenia polityk gospodarczych (podatki, cła), Smith w obydwu dziełach (WN i LJ) ${ }^{11}$ analizował także kwestię finansowania wymiaru sprawiedliwości (Smith, 1869, II, V).

Podstawą dla rozważań Smitha na temat relacji między normami moralnymi i prawnymi było szkockie oświecenie. Według moralistów szkockich etyka nie dotyczyła spraw osobistych, lecz była uprawiana z punktu widzenia organizatora życia zbiorowego. Smith poszukiwał źródeł sądów moralnych w uczuciach, gdyż rozum miał spełniać rolę instrumentalną ${ }^{12}$.

Człowiek według Smitha jest istotą społeczną, która wśród innych buduje swoją tożsamość, od nich uczy się moralności i wydawania ocen moralnych. $\mathrm{Z}$ otoczenia czerpie zwyczaje, poglądy, wzorce postępowania. Smith podkreślał $\mathrm{z}$ jednej strony wpływ społeczeństwa na jednostkę, z drugiej wpływ jednostki na społeczeństwo. Zarówno normy moralne, kanony estetyczne, jak i mechanizmy ustalania cen są wynikiem zachowań, decyzji i interakcji. Podkreślał obustronne relacje między jednostką a społeczeństwem - jest to proces ciągły, w których istotną rolę odgrywają „niezamierzone konsekwencje” (Markwart, 2017, s. 270). Człowiek, negatywnie oddziałując na ludzi, „krzywdzi sam siebie”, gdyż jest członkiem społeczeństwa. „Człowiek mądry i szlachetny pragnie poświęcić osobistą korzyść na rzecz korzyści ogółu”, a „podrzędne korzyści podporządkowywać większej korzyści świata”. „[...] Czyjeś szczęście zależy od szczęścia współobywateli” (Smith, 1989, VI, II). Smith wskazywał na trójstopniową procedurę oceny zachowania człowieka. Pierwszym, naturalnym punktem odniesienia jest społeczeństwo, „,bezstronny widz - obserwator” - osąd całości społeczeństwa. Drugim własne sumienie (człowiek ocenia normy i reguły, którym ma się podporządkować) z uwzględnieniem bezstronnego obserwatora, usytuowanego między człowiekiem a Bogiem. Trzecia instancja to autorytet Stwórcy - Natury (Markwart, 2017, s. 279).

\footnotetext{
${ }^{11}$ Przez cały okres, w którym opłaty za wymiar sprawiedliwości miały charakter prywatny, ryzyko korupcji było wysokie. Zdaniem Smitha wynagrodzenie sędziów nie powinno być wypłacane według uznania władzy wykonawczej lub osób zaangażowanych w proces, lecz z dochodów państwa (system finansów publicznych), ponieważ system sprawiedliwości przynosi korzyści wszystkim obywatelom. Postulował także odłączenie wymiaru sprawiedliwości od władzy wykonawczej. W Anglii wprowadzono system stałego wynagrodzenia sędziów, którego źródło stanowiły podatki (Smith, 1954, t. II, V, I).

${ }^{12}$ Ogólne reguły moralności tworzy się na podstawie obserwacji, wykorzystując rozumowanie indukcyjne.
} 
Pozwala to odpowiedzieć na tzw. Das Adam Smith Problem ${ }^{13}$, sprowadzający się do tezy o rozbieżności teorii Smitha między TSM i WN. We współczesnej literaturze przedmiotu naukowcy dzielą się na zwolenników koncepcji dominującej roli egoizmu, czyli egocentrycznej postawy człowieka odłączonej od etyki ${ }^{14}$ oraz admiratorów holistycznej interpretacji prac Smitha ${ }^{15}$.

W tym duchu V. Smith twierdzi, że relacje szkockiego myśliciela o ludzkich zachowaniach koncentrują się na współpracy i wzajemności. W sferze moralnej ludzie maksymalizują zyski z wymiany społecznej, podczas gdy w sferze ekonomicznej maksymalizują zyski z wymiany materialnej (Smith, 1997, s. 18). Egoistyczne intencje jednostki osłabia w sferze moralnej zasada sympatii ${ }^{16}$ oraz „bezstronny obserwator" (Smith, 1989, II, II) ${ }^{17}$, którym może być także państwo, oceniając, kiedy ktoś został „ranny”. Państwo musi następnie zaprojektować i zastosować prawo cywilne i karne, aby zapobiec „dalszym obrażeniom” i ukarać przestępców. Należy zgodzić się z B. Pogonowską (1996, s. 78), że różnorodność i wielowątkowość stosowanej przez Smitha argumentacji nie jest w żadnym sensie świadectwem niespójności poglądów uczonego.

Łącznikiem między moralnością a prawem była zasada (cnota) sprawiedliwości, która pojawia się w trzech pracach Smitha ${ }^{18}$. Przedmiotem sprawiedliwości jest zabezpieczenie przed „zranieniem” i stanowi ona podstawę rządu cywilnego (Smith, 1869, I, 5). Zasada sprawiedliwości, fundamentalna dla powstawania i trwania społeczeństw, jest ważniejsza od interesu własnego oraz jest ścisłą i precyzyjną zasadą moralną, ważniejszą niż sympatia (Smith, 1989, II $)^{19}$.

Naturalne skłonności człowieka do egoizmu mogą stać się istotnym zagrożeniem, gdy przekroczą „granicę”, która dotyczy wolności innych osób. Każdy człowiek ma przede wszystkim prawa naturalne, w związku z tym dążenie do interesu własnego musi odbywać się z poszanowaniem tych praw. Dlatego Smith widział potrzebę prawnego ograniczenia wolności człowieka gospodarującego w sytuacji naruszenia tych praw. „Niewidzialna ręka Smitha” jest uzupełniana „widzialną ręką prawa”. Prawo nie jest pojmowane jako wytwór rozumu lub jako zaplanowana instytucja, lecz jako dziejący się proces stałego odkrywania naturalnej moralności, ale jest to jednak działanie zewnętrzne względem człowieka.

\footnotetext{
${ }^{13}$ Sformułowali to myśliciele niemieccy (przede wszystkim H. Buckie i W. von Skarżyński).

${ }^{14}$ Przykładowo A. Greenspan (2005), G. Stigler (1971, s. 265).

15 Taki pogląd prezentują R.P. Hanley (2009, s. 50), A. Sen (2010, s. 51).

16 Smith wprowadził kategorię „,sympatii” jednocześnie z wyrażeniem „współodczuwanie”, które dobrze oddaje istotę sympatii.

17 To znaczy taki, który nie opowiada się za żadną ze stron. Ma pełną informację dotyczącą danej osoby i sytuacji oraz pozbawiony jest wszelkich emocji. Tak więc słynne twierdzenie Smitha o piwowarze i piekarzu (Smith, 1954, t. I, II), które zakłada założenie istotne dla funkcjonowania gospodarki rynkowej: społeczeństwo oparte na ogólnej akceptacji moralnej zasady sympatii jest wyposażone w instytucje administracyjne i prawne niezbędne do radzenia sobie z przypadkami, w których wspólna moralność jest naruszana. Z drugiej strony wielokrotnie cytowany fragment Bogactwa narodów Smitha jest obecnie wykorzystywany także w teorii ,agent - pryncypał” oraz dotyczy kosztów transakcji (Przybyła, 2005, s. 25).

${ }^{18}$ Do cnót zalicza on właściwość postępowania (propriety), roztropność (prudencence), życzliwość (benevolence), sprawiedliwość (justice), dobroczynność (beneficence). Kategorie te stały się podstawą etyki mieszczańskiej.

${ }^{19} \mathrm{Na}$ wyższym poziomie odnosi się do całego systemu wymiaru sprawiedliwości (Smith, 1989, VII, IV).
} 
Każdy system prawa pozytywnego można uważać za mniej lub bardziej niedoskonałą próbę przybliżenia się do prawoznawstwa naturalnego, czyli do wyliczenia poszczególnych reguł sprawiedliwości, ,ponieważ z naruszeniem sprawiedliwości ludzie, wszyscy razem i każdy z osobna, nigdy się nie pogodzą, sądy publiczne z konieczności muszą wykorzystywać autorytet państwowy do wzmocnienia praktyki tej cnoty" (Smith, 1989, VII, IV). Uznawał przy tym trzy sposoby wprowadzania reguł sprawiedliwości: na podstawie formalnej ustawy, zwyczaju lub „oczywistego poczucia sprawiedliwości"20. Pozytywne prawo danego społeczeństwa, jako prawo uznane przez jego suwerenną władzę (polecenie suwerena), może odejść od prawa naturalnego, ale gdy to robi, prawo pozytywne staje się niesprawiedliwe (VII, IV). Utrzymywanie i wymierzanie sprawiedliwości to jedna z funkcji państwa, na które godzi się także w WN. Istnienie wymiaru sprawiedliwości pozwala utrzymać harmonię i bezpieczeństwo, będące warunkiem rozwoju gospodarczego (I, III).

Smith sprawnie analizował poszczególne gałęzie prawa w kontekście moralności. W kwestii prawa karnego dostrzegał podstawową zasadę, zgodnie z którą osoby, które dokonały szkody (injures), muszą zrekompensować swoim ofiarom „oczywiste przyczyny, bez żadnego wyjaśnienia” (Smith, 1869, I, § I, XIII). Teoria kar kryminalnych Smitha opiera się na jego teorii moralnej: „miarą kary wymierzonej przestępcy jest zbieżność bezstronnego widza $\mathrm{z}$ niechęcią rannych" $(104)^{21}$. Nie zgadzał się z założeniem, że rząd będzie karał w optymalny sposób. Twierdził, że im bardziej interesy rządu zostaną naruszone, tym kary będą surowsze, podając jako przykład zakaz eksportu wełny w 1614 r. (MacCormick, 1981, s. 248).

Smith sądził, że sprawiedliwość polega przede wszystkim na nienaruszaniu panującego porządku, prawa do życia, własności i wolności osobistej, na drugim miejscu wskazywał na nakazy dotyczące dotrzymywania umów i przyrzeczeń. Korzystna dla wszystkich stron wymiana gospodarcza musiała się dokonywać przede wszystkim w ramach prawnych. Granicę krańcową sprawiedliwości wyznaczało zabezpieczenie przed „zranieniami”22, które mogą dotyczyć członka rodziny (osoby, jej ciała lub wolności), członka państwa (reputacji) oraz w ramach majątku (własności) (Smith, 1869, I, 5). Dwa pierwsze rodzaje zadawania krzywd były podstawą wyróżnienia praw naturalnych, ostatni - praw nabytych iura adventitia $\mathrm{np}$. do majątku, dwojakiego rodzaju: prawdziwych i osobistych ${ }^{23}$. Prawa nabyte osobiste to prawa kontraktu, quasi-kontraktu, wykroczenia i odszkodowania. Prawa nabyte prawdziwe to własność (nabywana na 5 sposobów), służebności (np. gruntowe - dostęp do drogi) ${ }^{24}$, zobowiązania (np. kredyty hipoteczne) i wyłączne

\footnotetext{
${ }^{20}$ Prawo zwyczajowe musi zostać uzupełnione ustawą (jednym z powodów jest potrzeba kontrolowania sędziów), standardem prawa ustawowego powinien być naturalny powód (casus), a nie wola prawodawcy (Smith, 1998).

${ }^{21}$ Tu różni się od koncepcji Pufendorfa i Grotiusa.

${ }^{22}$ Prawa zostały określone społecznie.

${ }^{23}$ Prawa te mogą mieć „naturalne” podstawy, ich ochrona i egzekwowanie są sprawami regulowanymi przez prawo pozytywne (MacCormick, 1981, s. 245).

${ }^{24}$ Twierdził, że służebności powstały jako umowy dwustronne, dzięki którym rolnik mógł np. zezwolić sąsiadowi na przemierzenie jego własności, aby uzyskać dostęp do drogi. Analizując, co stanie się ze służebnością w kontekście sprzedaży gruntów, podnosił znaczenie kosztów transakcyjnych dla rozwoju
} 
przywileje (prawa niematerialne, np. patenty lub prawo spadkobiercy, który nie wszedł jeszcze w dziedziczenie) ${ }^{25}$.

Własność to jedna z najbardziej istotnych kategorii zarówno dla prawa, jak i ekonomii.

Zgodnie z prawem anglosaskim to wiązka praw (Buława \& Szmit, 2012, s. 100). Własność nie jest prawem przyrodzonym, odwiecznym, istnieje, gdyż jest użyteczna jak prawo dziedziczenia i obowiązek dotrzymywania umów. Podstawą dyskusji Smitha na temat prawa własności jest teoria „czterech etapów” stosowana zarówno $\mathrm{w} \mathrm{WN}$ i $\mathrm{LJ}^{26}$. Według Smitha narody przechodzą przez cztery etapy rozwoju kulturowego, społecznego i gospodarczego, które nazywa wiekiem myśliwych, pasterzy, rolnictwa i handlu, rozszerzając zakres oddziaływania prawa ${ }^{27}$.

Podstawą rozumowania jest twierdzenie, że istnieje związek między prawami własności a rozwojem gospodarczym ${ }^{28}$. Na etapie, w którym nie było rozwiniętego systemu własności prywatnej, potęgującej nierówności społeczne, nie utrzymywano „magistratów i urzędów” (Smith, 1869, § II, XIV) ${ }^{29}$.

Smith wyjaśniał, że w erze myśliwych prawa były w fazie zalążkowej, własność znacznie rozwinęła się w erze pasterzy, natomiast epoka rolnictwa charakteryzowała się dominacją praw do nieruchomości, co wpływało na rozwój prawa do dziedziczenia. Epoka handlu przyniosła rozwój transferów własności oraz szeroko pojętej wolności. Ewolucyjna analiza Smitha o rozwoju prawa i porządku w epoce handlu wyjaśnia również ogólny spadek surowości kar. W okresie feudalizmu istniał niższy poziom bezpieczeństwa i statystycznie wyższa możliwość popełniania przestępstw (Smith, 1869, s. 129). Smith zwracał uwagę na bezpieczeństwo prawa własności, które umożliwia działalność gospodarczą oraz inwestycje gospodarcze. Bezpieczeństwo nieruchomości stanowi zachętę do prowadzenia działalności gospodarczej. $Z$ jednej strony rozwój prawa jest według Smitha determinowany rozwojem gospodarczym. Z drugiej rozumiał, że to regulacje prawne ograniczają lub rozszerzają zakres wolności gospodarczej. Władze majątkowe i cywilne są współzależne (107). Zapotrzebowanie na konkretne prawa stanowi wyraz ewolucjonizmu Smitha. Prawa obowiązujące w poszczególnych krajach nie zawsze przystają do tego, co nakazywałaby sprawiedliwość. Reguły podlegają zmianom, podobnie jak procedury, obyczaje i potrzeby. Identyfikacja praw spra-

gospodarczego. Współcześnie koszty transakcji to koszty definiowania, egzekwowania, ochrony i transferu uprawnień własnościowych (Smith, 1869, II, § 6, 128).

${ }^{25}$ Także prawo dziedziczenia (Smith, 1954, t. I, IV, V).

${ }^{26}$ M. Okan (2017, s. 1247) analizuje przedstawioną w WN gospodarkę kapitalistyczną ze szczególnym uwzględnieniem kapitału i podziału pracy, natomiast na podstawie lektury LJ wyjaśnia ewolucję instytucji w kontekście finansów publicznych.

${ }^{27}$ Smith pokazał to na przykładach Arabów, łowców indyjskich, pasterzy tatarskich, ludów germańskich rolników, miast handlowych, Aten i Rzymu itd. Analiza 4 etapów jest zbliżona do teorii H. Demsetza oraz R. Coase. Demsetz twierdzi, że ekonomicznym celem praw własności jest internalizacja efektów zewnętrznych, które powstają w odpowiedzi na nowe lub zmienione koszty zewnętrzne lub korzyści. Ilustruje tę tezę poprzez dyskusję na temat tworzenia praw własności na ziemi wśród plemienia indiańskiego, które przypomina opis Smitha. Podobna analiza występuje w WN (Piqué, 2016, s. 95).

${ }^{28}$ Teoria praw własności powstała w latach 60 XX w. (Ratajczak, 2014, s. 147).

${ }^{29}$ Gdzie nie ma własności, która przekraczałaby wartość dwóch lub trzech dni pracy, tam władza państwowa nie jest tak bardzo potrzebna (MacCormick, 1981, s. 250; Smith, 1954, t. I, V, I). 
wiedliwości i mechanizmów psychologicznych, które ograniczają nasze dążenie do własnego interesu ${ }^{30}$, jest częścią ekonomii politycznej Smitha ${ }^{31}$, a także jego teorii moralnej.

Państwo pojawiło się w historii, kiedy stało się to konieczne w celu ochrony prawa własności przed naruszaniem i egzekwowaniem kontraktów oraz spłatą długów, gdyż rządy prawa utrudniają możliwość zdobycia bogactwa za pomocą przemocy (Smith, 1989, I, III) - ochrona bogatych przed biednymi ${ }^{32}$. Prawa własności gruntów to podstawa dla rozwoju podziału pracy i jej pozytywnych efektów (II, § 5), co z kolei wynika z naturalnej skłonności do wymiany, jednego z głównych motywów postępowania ludzkiego. Podział pracy był rezultatem i ostatecznym wyrazem bogactwa oraz wolności gospodarczej i politycznej.

Zasady, reguły postępowania są przedmiotem nauk społecznych, w tym jurysprudencji naturalnej. Prawo w społeczeństwie komercyjnym jest środkiem, za pomocą którego państwo promuje dobrobyt publiczny. Smith zwracał uwagę na podstawowe znaczenie prawa dla właściwego funkcjonowania mechanizmu rynkowego i wymiany dóbr. W związku z tym przepisy dotyczące handlu i produkcji muszą być według niego tworzone w taki sposób, aby zachęcać, zamiast ingerować W zdolności produkcyjne (Mahoney, 2017). Ponadto prawo nie powinno również tworzyć warunków sprzyjających uprzywilejowaniu niektórych grup czy gałęzi wytwórczości przez nakładanie ceł bądź uchwalanie przychylnych ustaw. Smith wskazywał na negatywne skutki przepisów o terminowaniu, które tamowały swobodny przepływ pracy, podobnie jak prawa ubogich, zaś proces zacofania rolnictwa szkockiego wyjaśniał, wskazując na prawodawstwo ograniczające terminy umów dzierżawnych (Smith, 1954, t. I, I, XI). Mimo że doceniał rolę banków, postulował wprowadzenie regulacji ich działania. Ostatnim instrumentem prawnym hamującym swobodny przepływ pracy i kapitału miały być ustalenia dotyczące stawek płac oraz cen żywności ${ }^{33}$. Wskazywał także na funkcjonowanie praw, które nie odpowiadają już realiom społecznym, np. prawo primogenitury ${ }^{34}$ czy też zagadnienia, które powinny być regulowane przez prawo, np. regulacja stopy procentowej. Zakładając, że natura ludzka jest statyczna, teoria prawa naturalnego sugeruje istnienie jednego systemu sprawiedliwości. Niektóre reguły prawne, takie jak: prawa własności, prawny obowiązek naprawienia szkody spowodowanej przez niektóre czyny uznane za bezprawne są na ogół charakterystyczne dla wysoko rozwiniętych społeczeństw, np. komercyjnego.

\footnotetext{
${ }^{30}$ Interes własny pojawia się także w LJ. „Człowiek, w ten sam sposób, skupia się na miłości własnej (selflove) pobratymców, proponując im pokusę wystarczającą, by uzyskać to, czego chce” (Smith, 1869, II §V).

31 „Ekonomia polityczna, uważana za gałąź nauki męża stanu lub prawodawcy, proponuje [...] wzbogacić zarówno lud, jak i suwerena" (Smith, 1954, t. I, IV).

${ }^{32} \mathrm{~W}$ konsekwencji biedni będą mieli znacznie wyższy standard życia w systemie, w którym nieruchomość była zabezpieczona, niż w tym, w którym nieruchomość była niepewna.

${ }^{33} \mathrm{Nie}$ popierał deregulacji w sposób absolutny, o czym świadczy uznanie dla aktu nawigacyjnego (z 1651 r.), istotnie ograniczającego wolność handlu morskiego (Lis, 2014, s. 302; Smith, 1954, t. II, 7).

${ }^{34}$ Smith wyjaśnił ekonomiczne skutki primogenitury. Wydaje się, że stanowisko to jest bliskie późniejszej teorii tzw. nieodpłatnych transferów J. Buchanana. Zasady dziedziczenia tworzą system bezpieczeństwa państwa (Mahoney, 2017, s. 8).
} 
Prawo pozytywne według Smitha nie stanowi substytutu moralności, lecz jego wzmocnienie i jest niezależne od konkretnych społeczeństw. Legitymizacja państwa dokonuje się na podstawie zasady użyteczności (utility) ${ }^{35}$. Smith nie jest zwolennikiem koncepcji umowy społecznej typu hobbesowskiego (kontraktualizm). Sprawiedliwość dla Smitha to warunek sine qua non dla społeczeństwa, aby się nie rozpadło. Państwo pojawiało się więc jako niezbędny instrument wymuszania sprawiedliwości, akceptowanej przez ludzi głównie poprzez ich naturalne poczucie sprawiedliwości (Smith, 1989, VII, IV) oraz edukację, która „będzie wstępem do formowania się cnotliwych jednostek, które w większości przypadków szanują sądy społeczeństwa i prawo państwowe”. Teoria Smitha połączyła koncepcje prawa naturalnego i logikę ewolucyjną, podkreśliła zdecentralizowany, konkurencyjny charakter rynków wspieranych przez bezpieczne prawa własności i swobodę zawierania umów, przyjęła ogólnie sceptyczną postawę wobec interwencji państwa i argumentowała, że angielskie common law w wielu aspektach jest zgodne z naturalną wolnością ${ }^{36}$.

\section{Podsumowanie}

Ekonomia, etyka i jurysprudencja według Smitha są ściśle powiązane zarówno merytorycznie, jak i metodologicznie. Smith we wszystkich pracach posługiwał się metodą teoretyczną i weryfikował ją empirycznie. Jego koncepcje powstały na podstawie obserwacji, doznań i uczuć jednostki żyjącej w społeczeństwie. Według Smitha prawo jest sformalizowanym wyrazem naturalnej sprawiedliwości. Teoria sprawiedliwości zaś to moralna teoria praw. Wydaje się, że motywacja do budowy systemu prawnego $\mathrm{w}$ toku ewolucji społeczeństw miała charakter ekonomiczny i sprowadzała się do ochrony własności, gdyż to bezpieczeństwo praw własności promuje rozwój gospodarczy. Smith podkreślał znaczenie niezależnego sądownictwa dla zapewnienia ochrony własność i „świętości umów”. Podstawą dla rozwoju jurysprudencji były istotne „ograniczenia” w zakresie sankcji wynikających $\mathrm{z}$ oddziaływania samych norm moralnych w społeczeństwie. Wprawdzie ludzie mają wrodzone i instynktowne reakcje na niesprawiedliwość i krzywdę innych w postaci „zemsty”, jednak moralność wynikająca z interakcji ludzi musi być wraz z rozwojem społeczeństw i ich potrzeb wzbogacona normami prawnymi narzuconymi z zewnątrz, gdy istnieje ku temu społecznie weryfikowana potrzeba. Smith ze względu na „osąd społeczny” i „wewnętrzną sprawiedliwość” jednostki

\footnotetext{
${ }^{35} \mathrm{Nie}$ był to utylitaryzm benthamowski rozumiany jako system konsekwencjalistyczny (liczą się skutki). Tezy Benthama znalazły się w opozycji do Smitha i Blackstone’a. Postulaty Benthama znalazły wyraz w społeczeństwie angielskim i stały się pobudką do podjęcia w latach 30 . XIX w. prac nad kodyfikowaniem prawa karnego oraz stanowią podstawę pozytywizmu prawniczego, w ekonomii zaś marginalizmu. Metodologia Benthama była podstawą pierwszej fali ekonomicznej analizy prawa i stała się dominująca (Young, 2005, s. 101, 104).

${ }^{36}$ Niemniej jednak wiara $w$ istnienie praw naturalnych i ich znaczenie dla metody prawa zwyczajowego ostatecznie ustąpiła w Ameryce, podobnie jak w Anglii, twierdzeniom reformatorów, którzy $\mathrm{z}$ powodzeniem forsowali czynne zaangażowanie legislacyjne w życie społeczne i gospodarcze.
} 
postrzegał rolę i znaczenie prawa nie tylko przez pryzmat przymusu państwowego. Uznawał, że prawo odwołuje się do tych samych źródeł co nasze przekonania moralne. W związków z tym prawo ma nie tylko charakter egzogeniczny, ale w pewnym stopniu także endogeniczny. Społeczeństwo nie może przetrwać bez egzekwowania sprawiedliwości, której zasady są minimalnymi wymaganiami dla zaistnienia i funkcjonowania społeczeństwa rynkowego. Smith wierzył w wymierzanie sprawiedliwości za pomocą aparatu państwa (sędziów). Ponadto nie podjął się oddzielenia prawa od nauki ekonomicznej i moralności. Działania gospodarcze są ograniczane normami prawnymi, społecznymi i moralnymi oraz, przede wszystkim, sprawiedliwością. Warto podkreślić, że system naturalnej wolności Smitha zrodził się w prawie zwyczajowym. Kapitalizm stał się najwyższym stopniem ekonomicznej i moralnej doskonałości. Smith, eksponując rolę i znaczenie podziału pracy, potwierdził, że jest on łącznikiem między podejściami: ekonomicznym, etycznym i prawnym, gdyż przyczynia się do kreowania bogactwa i łączy się z wolnością. Ta teza przyczyniała się do powstania WN.

\section{Bibliografia}

Brühlmeier, D. (2004). Adam Smith. Warszawa: DIG.

Buława, P., \& Szmit, K. (2012). Ekonomiczna analiza prawa. Warszawa: Wolters Kluwers.

Chodorowski, J. (2002). Adam Smith (1723-1790). Życie i dzieło autora badań nad natura i przyczynami bogactwa narodów. Wrocław: Wydawnictwo Uniwersytetu Wrocławskiego.

Dubber, M.D. (2005). The police power: Patriarchy and the foundations of American government. Nowy Jork: Columbia University Press.

Dziadzio, A. (2002). Powszechna historia prawa. Warszawa: Wydawnictwo Naukowe PWN.

Greenspan, A. (2005). Adam Smith. speech held at Adam Smith Memorial Lecture. Kirkcaldy, Scotland. Speech from Board of Governors of the Federal Reserve System (U.S.).

Haakonssen, K. (1989). The science of a legislator: The natural jurisprudence of David Hume and Adam Smith. Cambridge University Press.

Hanley, R.P. (2009). Adam Smith and the character of virtue. Cambridge University Press.

Hühn, M.P. (2019). Adam Smith's philosophy of science: Economics as moral imagination. Journal of Business Ethics, 155(2), 1-15. https://doi.org/ 10.1007/s10551-017-3548-9

Young, J.T. (2005). Unintended order and intervention: Adam Smith's theory of the role of the state. History of Political Economy, 37(5), 91-119. 
Klimczak, B. (1993). Etyka gospodarcza. Wrocław: Wydawnictwo Akademii Ekonomicznej im. Oskara Langego.

Lis, R. (2014). Ku społeczeństwu cywilnemu i bogactwu narodów. Główne koncepcje polityczne i prawne szkockiego Oświecenia. Kraków: Wydawnictwo WAM.

MacCormick, N. (1981). Adam Smith on law. Valparaiso University Law Review, 15(2), 243-263.

Mahoney, P.G. (2017). Adam Smith, prophet of Law \& Economics. Journal of Legal Studies, 46(1), 207-236.

Markwart, A. (2017). Bogactwo uczuć moralnych. Jednostka i społeczeństwo we wzajemnych oddziaływaniach $w$ perspektywie filozofii Adama Smitha. Toruń: Wydawnictwo Naukowe Uniwersytetu Mikołaja Kopernika.

Okan, M. (2017). How did it all begin? Adam Smith on the early and rude state of society and the age of hunters. European Journal of the History of Economic Thought, 24(6), 1247-1276.

Piqué, P. (2016). Adam Smith on governance and regulation. An account of his lectures on jurisprudence. Journal of Governance and Regulation, 5(4), 90-98. http://doi.org/10.22495/jgr_v5_i4_p8

Pogonowska, B. (1996). Kategoria racjonalności $w$ teoriach podmiotowych makroekonomii. Poznań: Akademia Ekonomiczna.

Przybyła, H. (2005). Adam Smith - prekursor etyki gospodarczej. Studia Ekonomiczne, 35, 11-49.

Ratajczak, M. (2014). Współczesne teorie ekonomiczne. Poznań: Wydawnictwo Uniwersytetu Ekonomicznego.

Sandmo, A. (2011). Economics evolving. A history of economic thought. Princeton University Press.

Sen, A. (2010). Adam Smith and the contemporary word. Erasmus Journal for Philosophy and Economics, 3(1), 50-67. https://doi.org/10.23941/ejpe.v3i1.39

Smith, A. (1869) Adam Smith, Lectures on justice, police, revenue and arms. Oxford: Clarendon Press.

Smith, A. (1954). Badania nad natura i przyczynami bogactwa narodów. Warszawa: Państwowe Wydawnictwo Naukowe.

Smith, A. (1989). Teoria uczuć moralnych. Warszawa: Państwowe Wydawnictwo Naukowe.

Smith, V.L. (1997). The two faces of Adam Smith. Southern Economic Journal, 65(1), 2-19. https://doi.org/0.3366/jsp.2017.0153

Stigler, G.J. (1971). Smith's travels on the ship of state. History of Political Economy, 3(2), 265-277. https://doi.org/10.1215/00182702-3-2-265

Zabieglik, S. (1997). Wiek Doskonalenia. Z filozofii szkockiego oświecenia. Zeszyty Naukowe Politechniki Gdańskiej, 558, 8-48.

Zirk-Sadowski, M. (2011). Wprowadzenie do filozofii prawa. Warszawa: Wolters Kluwer. 